\title{
Beliefs: Quality Teaching Practicum Vs Quality Teachers
}

Chan, G.C. ${ }^{1}$, Yunus, M. M. ${ }^{2}$, Embi, M. A. B. ${ }^{3}$

${ }^{1,2,3}$ Falculty of Education, The National University of Malaysia

Corresponding email: chooguichan@gmail.com

\begin{abstract}
Teaching practicum is one of the important aspects in teacher education programme as it concerns preparation of quality teachers and it embraces all the learning experiences of pre-service teachers in schools. Teaching practicum is a real challenge for the pre-service teachers because their performance during teaching practicum will foreshadow the future success of the pre-service teachers. Therefore, the aim of this paper is to investigate Teaching English as a Second Language (TESL) pre-service teachers' beliefs about teaching practicum and identify what components of teacher education programme that contribute preservice teachers' views about teaching practicum. Data was collected via a questionnaire survey of third year TESL undergraduates from University of Malaya. The data was analyzed using descriptive statistics. The findings will be presented and elaborated upon in this paper. For further understanding, this paper also discusses the pre-service teachers' beliefs according to the two main aspects namely, (i) importance of teaching practicum and (ii) confidence and uncertainty about teaching practicum.
\end{abstract}

Keywords: Pre-Service Teachers; Beliefs; Teaching Practicum

DOI: http://dx.doi.org/10.20961/ijpte.v3i1.26210 


\section{INTRODUCTION}

Teaching practicum is an important component in teacher education programme. It is meant for pre-service teachers to master and practice all the concepts, principles, skills and values and eventually apply the theories that they have learnt in the classrooms in order to become a quality and professional teacher. Yunus (2016) claims there are several factors that help to shape teachers' teaching practices. Namely (1) teacher personality and style mattered more than methodology; (2) teachers were caring and committed, and had clear expectations of their students; (3) teachers respected, and were respected by the students; (4) learning was facilitated by a positive classroom environment.

The existing beliefs of pre-service teachers should be considered in the teacher education programme as these beliefs interact with their learning process (Esen Uzuntiryaki, 2007). Such beliefs would influence pre-service teachers to interpret and analyse the pedagogical knowledge, conceptualization of teaching tasks, their teaching decisions and their classroom practice (Pajares, 1992). Although there are lots of theories and pedagogies that have been taught via the teacher education programme, there are still a lot of pre-service teachers who are not ready to face the challenges in the classroom when it is time for them to go for teaching practicum. Therefore, throughout the teacher education programme, it is very important for the lecturers to identify student teachers' beliefs about teaching practicum before they go for real teaching and encourage them to reflect upon these beliefs (Esen Uzuntiryaki, 2007).

The aim of this paper to investigate University of Malaya TESL undergraduates' beliefs about teaching practicum. Data were gathered through surveys done by the pre-service teachers regarding (a) their prior beliefs about practicum orientation and (b) the components of Teacher Education Programme that contribute preservice teachers' views about teaching practicum.

\section{MALAYSIAN CONTEXT}

Teaching practicum is part of the teacher preparation programme. Every preservice teacher needs to undergo teaching practicum in order to complete their teaching courses so as University of Malaya TESL undergraduates. University of Malaya TESL undergraduates need to go for teaching practicum during their fourth year of studies in order to complete their course, Bachelor in Education (TESL) in University of Malaya.

Teaching practicum is an essential component for the preparation of the beginner teachers (Yunus, 2010). The purpose of teaching practicum is to produce a professional teacher in the future. It also acts as a platform for pre-service teachers to practice what they have learned throughout the course. Teacher Training Division of the Ministry of Education Malaysia claims teaching practice as a series of practical and systematic school experiences to help student teachers to become professional in their teaching career (Malaysia Education Ministry, 1990). 


\section{LITERATURE REVIEW}

\section{The concept of teaching practicum}

The term 'practicum' is used generically to refer to the different types of school attachment. Namely, school experience, teaching assistantship, teaching practice and so forth that pre-service students will be undergoing as part their initial teacher preparation programme. Placing the students in an extended field experience gives them the opportunity to assume the responsibilities of a practicing teaching (Yunus, 2010; Ewart and Straw, 2005).

The school-based practicum is designed to enable pre-service teachers to observe a teacher's real work of work, and to apply and refine the knowledge and skills acquired through course-work in classroom teaching. Pre-service teachers are expected to plan, teach, reflect and act through the guidance of a supervisor and mentor teacher during the teaching practicum (Johnson, 2015). During the teaching practicum, they will be exposed to school culture and learn to function as a member of a school staff beyond classroom teaching.

According to Yunus et. al. (2010), teaching practicum experiences that preservice teachers completed are linked to their courses and are critical to their growth and development as teachers. Furthermore, the teaching practicum provides the opportunity to make critical connections between theory and practice. Therefore, pre-service teachers may use the opportunities during the practicum to integrate education theory and practice and to widen their practical experiences. In short, teaching practicum programme is to equip future teachers with the essential experiences which can lead to the development of their professional competencies.

\section{What is belief?}

According to Michaela Borg (2001), belief is a proposition which may consciously or unconsciously held, is evaluative in that it is accepted as true by the individual, and there imbued with emotive commitment; further, it serves as guide to thought and behaviour. Belief is also defined as "thought to be a strong indicator of the decisions people make throughout their lives" (Azim \& Ahmed, 2014).

Besides, beliefs can be explained in terms of one's personal views, conceptions and theories (Thomson, 1992). Another study by Kagan (1992) shows that "teacher beliefs are particular form of personal knowledge that includes implicit assumptions about students, their learning, classrooms and the subject matter to be taught". No matter what one's beliefs are, the beliefs still play an important role in many aspects of teaching, as well as in life. It is because these beliefs help individuals make sense of the world, influencing how new information in perceived, and whether it is accepted or rejected. Nevertheless, beliefs differ from knowledge, although they are related to each other, in that beliefs do not always represent the truth. Beliefs are not only considered as discipline-dependent (Tsai, 
2002), but beliefs also include understandings, assumptions, images or propositions that are felt to be true (Kagan, 1992; Richardson, 1996).

\section{Pre-service teachers' beliefs about teaching practicum}

Prior to actual teaching experiences, pre-service teachers derive their initial views on teaching from at least two sources. Firstly, it comes from their personal experiences as students, consisting of their interactions with and exposures to various teachers throughout their school life, with such factors having a tendency to influence their reasons for career choice, as well as beliefs and practices on their professional lives (Ben-Petetz, 2003; Bramald, Hardman, \& Leat, 1995). Secondly, it results from pre-service teachers forming their conceptual repertoires as they undergo the formal training provided by teacher educational programs (Bermald, 1995; Dunkin, Precian, \& Nettle, 1994; Nettle, 1998), initially consisting of theoretical knowledge through foundation and methods courses, and eventually progressing or culminating into the application of such theories via the so-called practice teaching.

Pre-service teachers tend to hold idealistic and naive beliefs about the classroom environment (Polat, Kaya \& Ahdag, 2015; Rimm-Kaufman, Storm, Sawyer, Pianta, \& LaParo, 2006). However, these views might be challenged by the real classroom situations (Feiman-Nemser, 2001). Yunus et. al. (2011) states that the teachers need to understand that in many schools, students come from different cultures and backgrounds and each student deserves to be respected as an individual and their needs vary from one another. Thus, pre-service teachers are encouraged to establish positive relationship with their students in order to provide the learning opportunity as well as motivation they needed to be successful in both academic and life lessons.

\section{METHOD}

The research design used for carrying out this study was quantitative research. Quantitative research is conducted where the researcher decides what to study, ask specific, narrow questions, collect numeric data from samples, analyses these numbers using statistics and conducts in inquiry in objective manner (Creswell, 2005). Therefore, we find that survey is the most suitable method to evaluate and discover the beliefs about teaching practicum of third year TESL students who are studying in University of Malaya.

\section{PROCEDURES}

The subjects of this study were the 40 third year students who enrolled in the Bachelor of Teaching English as second language program. They were comprised of Malays, Chinese, Indians and Turkish who have not undergone teaching practicum. The sample of study consists of $85.4 \%$ of female respondents and $14.6 \%$ of male respondents. All the respondents are coming from the same age category. The participants, totally 41 of them are in the range of 20 -year-old to 24-year-old. A 35-item survey was divided into three sections, namely 
i. The Demographic Data

ii. Research Question 1: What are the University of Malaya TESL undergraduates' prior beliefs about teaching practicum?

iii. Research Question 2: What are the components of the teacher education programme that help to build student teachers' beliefs about teaching practicum?

There are 25 items all together to investigate their prior beliefs about teaching practicum. These items were divided into to two aspects of beliefs about prior to teaching practicum. They are the beliefs about the importance of teaching practicum and their certainty and uncertainty about teaching practicum. 10 items were set to investigate the component of the teacher education programme that help to build pre-serviced teachers' beliefs about teaching practicum.

\section{RESULTS}

All of the data are collected, processed and analyzed using the Statistical Package for the Social Science (SPSS). The data are statically analyzed by using frequency counts and percentage distribution. The percentage distribution is computed for determining the extent to which prospective student teachers' agreed or disagreed with the items referring to various beliefs on teaching practicum and the components of the Teacher Education program contribute to students' views about teaching practicum. The data is analyzed and presented in a form of table.

The findings are presented mainly in two parts, namely:

(i) The Demographic Data

(ii) Analysis of Data:

- Research Question 1: What are the University of Malaya TESL undergraduates' prior beliefs about teaching practicum?

- Research Question 2: What are the components of the teacher education program that help to build student teachers' beliefs about teaching practicum?

\section{(i) The Demographic Data}

Table 1: Distribution of respondent according to gender, age, race and second method.

\begin{tabular}{llcc}
\hline Items & & Frequency & Percentage (\%) \\
\hline Gender & Male & 6 & 14.6 \\
& Female & 35 & 85.4 \\
Age & Below 20 & & 0 \\
& $20-24$ & 0 & 100 \\
Race & Malay & 41 & 26.8 \\
& Chinese & 11 & 34.1 \\
& Indian & 14 & 22.0 \\
& Others & 9 & 17.1 \\
Second Method & & 7 & \\
Literature & & & 53.7 \\
Moral Studies & & 22 & 46.3 \\
\hline
\end{tabular}


The questionnaires are sent to 6 male undergraduates and 35 female undergraduates via email. The sample of study consists of $85.4 \%$ of female respondents and $14.6 \%$ of male respondents. All the respondents are coming from the same age category. The participants, totally 41 of them are in the range of 20year-old to 24-year-old.

The purpose of distributing the questionnaires to different races is to see if different races would have different beliefs about teaching practicum. The table shows that the questionnaires are given to 11 Malay (26.8\%), 14 Chinese (34.1\%), 9 Indian (22.0\%), and 7 other races (17.1\%), namely Kadaza, Iban, Kayan and so forth. Besides that, the number of undergraduates is fairly distributed with regards to their second method course. There are 22 of the undergraduates in Literature course and 19 undergraduates in Moral Education course.

\section{(ii) Analysis and interpretation of data}

\section{What are the pre-service teachers' belief about teaching practicum?}

There are 25 items all together to investigate their prior beliefs about teaching practicum. These items will be broken down according to two aspects of beliefs about prior to teaching practicum. They are the beliefs about the importance of teaching practicum and their certainty and uncertainty about teaching practicum. All results are expressed as percentages (\%).

Table 2: Aspect 1: Pre-service teachers' beliefs about the importance of teaching practicum.

\begin{tabular}{|c|c|c|c|}
\hline \multirow[t]{2}{*}{ Items } & \multicolumn{2}{|c|}{ Percentage $(\%)$} & \multirow[b]{2}{*}{$\mathrm{A}$ or $\mathrm{SA}$} \\
\hline & SD or D & $\mathrm{U}$ & \\
\hline $\begin{array}{l}\text { 1. Teaching practicum is a time to master } \\
\text { questioning techniques. }\end{array}$ & 70.7 & 22.0 & 7.3 \\
\hline $\begin{array}{l}\text { 2. Teaching practicum is a way to impart } \\
\text { appreciation of teachers' ethic. }\end{array}$ & 68.3 & 24.4 & 7.3 \\
\hline $\begin{array}{l}\text { 3. Teaching practicum is to develop } \\
\text { teacher-like personality. }\end{array}$ & 78.1 & 14.6 & 7.3 \\
\hline $\begin{array}{l}\text { 4. Teaching practicum is to help student } \\
\text { teachers to experience the real teaching } \\
\text { environment. }\end{array}$ & 90.2 & 2.4 & 7.3 \\
\hline $\begin{array}{l}\text { 5. Teaching practicum is practice organizational } \\
\text { ethic. }\end{array}$ & 73.2 & 22.0 & 4.9 \\
\hline
\end{tabular}

Note: $\mathrm{SD}=$ Strongly Disagree $\quad \mathrm{D}=$ Disagree $\quad \mathrm{U}=$ Uncertain $\quad \mathrm{A}=$ Agree $\quad \mathrm{SA}=$ Strongly Agree

Teaching practicum is a precious opportunity for pre-service teachers to experience themselves how to be a professional teacher. Table 2 shows that almost all of the participants, $90.2 \%$ of them believe that teaching practicum is to help pre-service teachers to experience the real teaching environment. While there are $78.1 \%$ of the participants find that teaching practicum is to develop teacherlife personality. The participants' rating also shows that teaching practicum is also important for student teachers to practice "organizational ethic" $(73.2 \%)$ as well as to master "questioning techniques" $(70.7 \%)$. More than half amount of the 
participants, which is $68.3 \%$ of the participants believe that teaching practicum is a way to impart appreciation of teachers' ethnic.

Table 3: Aspect 2: Pre-service teachers' certainty and uncertainty about teaching practicum.

\begin{tabular}{|c|c|c|c|}
\hline \multirow[t]{2}{*}{ Items } & \multicolumn{2}{|c|}{ Percentage (\%) } & \multirow[b]{2}{*}{ A or SA } \\
\hline & $\mathrm{SD}$ or $\mathrm{D}$ & $\mathrm{U}$ & \\
\hline $\begin{array}{l}\text { 1. Teaching practicum makes me feel anxious } \\
\text { and nervous. }\end{array}$ & 78.1 & 17.1 & 4.9 \\
\hline $\begin{array}{l}\text { 2. I would feel uncomfortable to talk in front } \\
\text { of the class. }\end{array}$ & 46.4 & 17.1 & 36.6 \\
\hline $\begin{array}{l}\text { 3. I find teaching practicum is difficult and } \\
\text { confusing. }\end{array}$ & 31.7 & 31.7 & 36.6 \\
\hline $\begin{array}{l}\text { 4. During teaching practicum, I will be } \\
\text { exposed to school culture and learn } \\
\text { to function as a member of school staffs. }\end{array}$ & 80.5 & 9.8 & 9.8 \\
\hline $\begin{array}{l}\text { 5. During teaching practicum, I am expected } \\
\text { to apply what I have learned theoretically. }\end{array}$ & 75.6 & 14.6 & 9.8 \\
\hline $\begin{array}{l}\text { 6. I will have difficulty teaching in front of } \\
\text { my supervisor. }\end{array}$ & 46.3 & 34.1 & 19.5 \\
\hline $\begin{array}{l}\text { 7. I will get along with my supervisor and } \\
\text { I'm excited to teach in front of her/him. }\end{array}$ & 17.0 & 56.1 & 26.9 \\
\hline $\begin{array}{l}\text { 8. During teaching practicum, I need to write } \\
\text { the learning outcomes precisely. }\end{array}$ & 70.7 & 24.4 & 4.9 \\
\hline $\begin{array}{l}\text { 9. It is important to select appropriate teaching } \\
\text { methods. }\end{array}$ & 87.8 & 4.9 & 7.3 \\
\hline $\begin{array}{l}\text { 10. Teaching is just following the syllabus } \\
\text { provided by the Ministry of Education. }\end{array}$ & 22.0 & 29.3 & 48.8 \\
\hline $\begin{array}{l}\text { 11. Selection of teaching resources is not } \\
\text { important. }\end{array}$ & 17.1 & 12.2 & 70.7 \\
\hline $\begin{array}{l}\text { 12. I have to produce interesting tasks for } \\
\text { every lesson. }\end{array}$ & 73.2 & 12.2 & 14.6 \\
\hline 13. Teaching requires little preparation. & 31.7 & 7.3 & 61.0 \\
\hline $\begin{array}{l}\text { 14. Preparation for teaching is not time } \\
\text { consuming. }\end{array}$ & 19.5 & 9.8 & 70.7 \\
\hline $\begin{array}{l}\text { 15. I will be able to work happily with other } \\
\text { teachers in the school. }\end{array}$ & 65.9 & 34.1 & 0 \\
\hline
\end{tabular}

Note: $\mathrm{SD}=$ Strongly Disagree $\quad \mathrm{D}=$ Disagree $\quad \mathrm{U}=$ Uncertain $\quad \mathrm{A}=$ Agree $\quad \mathrm{SA}=$ Strongly Agree

Table 3 shows the student teachers' beliefs about their certainty and uncertainty about teaching practicum. There are $87.8 \%$ of the participants believe that it is important to select appropriate teaching methods and $80.5 \%$ of them agree that they will be exposed to school culture and learn to function as a member of a school staffs. Though most of the pre-service teachers believe strongly that teaching practicum bring lots of benefits to them, there are $78.1 \%$ of the preservice teachers feel anxious and nervous about teaching practicum.

The result shows $75.6 \%$ of the participants believe that they need to apply what they have learned theoretically during the teaching practicum. There are $70.7 \%$ of the pre-service teachers agree that they need to write the learning outcomes precisely but they disagree the statement that preparation for teaching is not time 
consuming. In addition, $65.9 \%$ of the pre-service teachers believe that they are able to work happily with other teachers in school. It is good to see that preservice teachers have positive beliefs about their capability and their passion about teaching.

\section{What are the components of Teacher Education Programme that contribute student teachers' views about teaching practicum?}

Table 4: The components of Teacher Education Programme that contribute to pre-service teachers' view about teaching practicum.

\begin{tabular}{|c|c|c|c|c|}
\hline \multirow{2}{*}{\multicolumn{2}{|c|}{ Items }} & \multicolumn{3}{|c|}{ Percentage $(\%)$} \\
\hline & & SD or D & $\mathrm{U}$ & A or SA \\
\hline & $\begin{array}{l}\text { University courses namely: } \\
\text { (i) Relationship Ethnic } \\
\text { (Hubungan Etnik) } \\
\text { (ii) Management of Uniformed Unit } \\
\text { (Pengurusan Unit Beruniform) }\end{array}$ & 43.9 & 26.8 & 29.3 \\
\hline & $\begin{array}{l}\text { Simulated teaching / microteaching for } \\
\text { TESL. }\end{array}$ & 78.0 & 7.3 & 14.6 \\
\hline & $\begin{array}{l}\text { Professional education courses, namely: } \\
\text { (i) Foundation for TESL Methodology } \\
\text { (ii) Linguistics for English teachers }\end{array}$ & 63.4 & 24.4 & 12.2 \\
\hline & Interaction with peers/ course mates. & 82.9 & 7.3 & 9.8 \\
\hline & Interaction with lecturers. & 82.9 & 9.8 & 7.3 \\
\hline & Special seminars and training attended. & 61.0 & 22.0 & 17.1 \\
\hline & Extra-curricular activities participated in. & 56.1 & 26.8 & 17.1 \\
\hline & Conferences/consultations with lecturers. & 73.2 & 19.5 & 7.3 \\
\hline & $\begin{array}{l}\text { Experiences with academic and administrative } \\
\text { officials. }\end{array}$ & 65.9 & 24.4 & 9.7 \\
\hline & $\begin{array}{l}\text { General academic courses, namely: } \\
\text { (i) Basic philosophy and education in Malaysia } \\
\text { (ii) Basic physical education, health, and co-curr }\end{array}$ & 61.0 & 22.0 & 17.1 \\
\hline
\end{tabular}

Note: $\mathrm{SD}=$ Strongly Disagree $\quad \mathrm{D}=$ Disagree $\quad \mathrm{U}=$ Uncertain $\quad \mathrm{A}=$ Agree $\quad \mathrm{SA}=$ Strongly Agree

Research question 2 is to identify the factors contributing to the shaping of preservice teachers' beliefs about teaching practicum. The participants generally agreed that all the components of their teacher education programme which included in the questionnaire contributed to build their beliefs about teaching practicum.

To be specified, $82.9 \%$ of the participants strongly agreed that interaction with the peers, course mates and even lecturers will help them to build their beliefs about teaching practicum. In addition, there are $78.0 \%$ of the participants agreed that simulated teaching or microteaching for TESL contributed ideas to their view about teaching practicum.

There are $73.2 \%$ of the pre-service teachers agreed that attending conferences and consultation with lecturers help them to build the views about teaching practicum while $65.9 \%$ of them find that experiences with academic and administrative 
officials could be an important experience for them to understand more about teaching practicum.

\section{DISCUSSION AND IMPLICATIONS}

From this survey research that pre-service teachers from University of Malaya have very positive attitudes towards teaching practicum and certain confidence in themselves. Most of them placed hope and looking forward to go for teaching practicum and they brought hope to the future classroom as well. However, there are a few number of the student teachers who are still nervous and feel anxiety about teaching practicum.

\section{Research Question (1): Pre-service teachers' beliefs about teaching practicum}

\section{(i) Importance of teaching practicum}

Student teachers believe that teaching practicum is to help them to experience the real teaching environment. During teaching practicum, student teachers are able to practice their teaching in front of the students. Students' reactions and response will reflect if it is an effective way of teaching or just a boring lesson plan. Student teachers also believe that teaching practicum can provide student teacher with many great opportunities to practice their teaching and learning theories. At the same time, it helps student teachers to develop their own teaching and learning style and theories. Besides that, they find that teaching practicum also helps student teachers to develop teacher-like personalities and build teacher ethnic among the trainees. Student teachers are able to learn the school organizational practice through teaching practicum.

\section{(ii) Confidence and uncertainty about teaching practicum}

There are a lot of the student teachers' feel nervous and anxiety about teaching practicum. It may due to many reasons. Some argue that they may have problem producing creative and interesting lesson plan every day, while some claim that they afraid to deal with students or teachers in school. The uncertainty that rise in the students is because they are not got used to the organizational and they are not sure how teaching practicum works. Moreover, not many of the student teachers believe that they are able to get along with the supervisor and feel excited to teach in front of their supervisor. This uncertainty is also shaped based on their own experience in class. To them, supervisor may always be someone who is a strict. They find that teaching in front of the supervisor is just like having examination and it is not fun at all.

\section{Research Question (2): Components of teacher education program that contribute to shape their beliefs about teaching practicum.} (i) Interactions with the peers and lecturers

To student teachers' beliefs, interaction with peers and the lecturers affect their beliefs the most. Interaction is one of the way of exchanging ideas and information. Student teachers will get the information from their peers who have 
undergone teaching practicum. From their peers' experience, student teacher will shape and build their prior beliefs about teaching practicum before they go for teaching practicum.

\section{(ii) Simulated teaching and microteaching for TESL}

Simulated teaching is a way to prepare student before teaching practicum. In the simulated teaching course, students are required to do lesson plans and do microteaching in front of their peers and lecturers. Student teachers have the opportunity to practice how to teach, what to teach and how to make an effective lesson plan. Simulated teaching is the first step to help to let student to build their view about teaching practicum.

\section{(iii) Universities courses / General academic courses}

Compared to other aspects, student teachers believe that the universities courses and general academic courses do not really help them to build and shape their beliefs about teaching practicum. To them, the courses provided are an introduction for student teachers to realize the importance of teaching and teaching practicum. Those courses are also teaching students about the pedagogies, teaching methodology and teaching methods.

From the survey, we cannot deny that prior beliefs of student teachers can hinder them from learning about teaching. Therefore, teacher education institutes or universities should make changes to suit students' needs. The authority should have imparted positive beliefs so that student teachers' will shape their beliefs about teaching practicum correctly. If student teachers have incorrect beliefs about teaching practicum, it may negatively affect their future teaching career. Hence, it is important for programme instructor to change and modify the components of teacher education programme so that it can help to produce a positive thinking professional teacher.

Besides that, most of the teacher education programmes only provide microteaching and teaching practicum. I suggest that teacher education programme can provide some class observation to student teachers. In my opinion, if student teachers have more chances to involve and experience the classroom environment, student teachers are able to build and shape more vivid beliefs about teaching practicum. If student teachers have enough experiences about real classroom situation, they will not fear about the real classroom situation when student teachers are going for teaching practicum. Moreover, it can also boost student teachers' confidence about teaching and classroom management.

Student teachers need to develop strong self-efficacy. Yunus (2009) defines selfefficacy as a continuous process throughout life while Bandura (1994) defines self-efficacy as people's beliefs about their capabilities to produce designated levels of performance that exercise influence over events that affect their lives. Self-efficacy may continue to evolve throughout life as people acquire new skills, experiences, and understanding. It is important for pre-service teachers to develop 
strong self-efficacy. It is because "a person who possesses a strong as one who view challenging problems as tasks to be mastered, develop deeper interest in the activities in which they participate, form a stronger sense of commitment to their interests and activities and recover quickly from setbacks and disappointments" (Bandura, 1994).

\section{CONCLUSION}

Overall this study shows that student teachers on the whole show very positive beliefs and attitudes about teaching practicum. However, there are some student teachers who are still discouraged with their profession. It is because they have incorrect beliefs about teaching and most of them are lack of experience. It can be explained that a professional teacher needs to have capability to teach, prepare teaching material, produce a good lesson plan and get along with the students as well as other teachers or supervisor in the school. In short, no matter the preservice teachers have a right or wrong assumption about teaching practicum, a real and effective change in pre-service teachers' beliefs can only occur through a change in their practice as well as the way they behave.

\section{REFERENCES}

Bandura, A., \& Ramachaudran, V. S. (1994). Encyclopedia of human behavior. New York: Academic Press, 4, 71- 81.

Ben-Peretz, M., Mendelson, N., \& Kron, F. W. 2003. How teachers in different educational contexts view their roles. Teaching and Teacher Education, 19 (2), 277-290.

Borg, M. 2001. Key concepts in ELT: Teachers' beliefs. Retrieved from http://eltj.oxfordjournals.org/cgi/reprint/55/2/186.pdf

Bramald, R., Hardman, F., \& Leat, D. 199. Initial teacher trainees and their views of teaching and learning. Teaching and Teacher Education, 11 (1),23-31.

Creswell, J.W. \& Creswell, J.D. 2005. Mixed methods research: developments, debates, and dilemmas. In R.A. Swanson \& E.F. Holton (Eds.), Research in Organizations: Foundations and Methods of Inquiry. San Francisco, CA: Berrett-Koehler Publishers.

Dunkin, M., J., Precian, R. P., \& Nettle, E. B. (1994). Effects of formal teacher education upon student teacher's cognitions regarding teaching. Teaching and Teacher Education, 10(4), 395-408.

Esen, U. 2007. Turkish Pre-service Teachers' belief about the importance of teaching chemistry. Journal of Teacher Education, Vol.32, 4.

Feiman-Nemser, S. (2001). From preparation to practice: Designing a continuum to strengthen and sustain teaching.

Flores, M. A. 2006. Being a novice teacher in two different settings: Struggles, continuities, and discontinuities. Teacher College Record, 108 (10), 20212052 
Fraenkel, J. R. \& Wallen, N. E. 1996. How to design and evaluate research in education. New York: McGraw-Hill.

Johnson, K. R. (2015). Fourth Year Preservice Teachers' Perceptions of the Student Teaching Practicum in Abu Dhabi (Doctoral dissertation, Walden University)

Kagan, D. M. 1992. Professional growth among preservice and beginning teachers. Review of Educational Research, 62 (2) , 129-169.

Nettle, E. B. 1998. Stability and change in the beliefs of student teachers during practice teaching. Teaching and Teacher Education, 14(2), 193-204.

Parajes, M. F. 1992. Teachers' beliefs and educational research: Cleaning up a messy construct. Review of Educational Research, 62(3),307-332.

Polat, S., Kaya, S., \& Akdag, M. 2013. Investigating Pre-Service Teachers' Beliefs about Classroom Discipline. Educational Sciences: Theory and Practice, 13(2), 885-890.

Raths, J. (n.d.). Teachers' belief and teaching beliefs. Retrieved, from Richardson, V. 1996. The role of attitudes and beliefs in learning to teach. In John Sikula (Ed.), Handbook of research on teacher education ( $2^{\text {nd }}$ ed., pp.102119). New York, NY: Macmillan.

Rimm-Kaufman, S. E., Storm, M. D., Sawyer, B. E., Pianta, R. C., \& LaParo, K. M. (2006). The teacher belief q-sort: A measure of teachers' priorities in relation to disciplinary practices, teaching practices, and beliefs about children. Journal of School Psychology, 44, 141-165.

Robotham, D. 2003. Learning and training: Developing the competent learner. Journal of European Industrial Training, 27 (9), 473-480.

Tsai, C. C. (2002). Nested epistemologies: science teachers' beliefs of teaching, learning and science. International journal of science education, 24(8), 771783.

Yunus, M. M., Hashim, H., Ishak, N. M., \& Mahamod, Z. 2010. Understanding TESL pre-service teachers' teaching experiences and challenges via postpracticum reflection forms. Procedia-Social and Behavioral Sciences, 9, 722-728.

Yunus, M. M., Nordin, N., Salehi, H., Embi, M. A., \& Mahamod, Z. 2013. Managing problems and planning activities involving ICT tools in teaching ESL reading and writing. Asian Social Science, 9(10), 222.

Yunus, M. M., Osman, W. S. W., \& Ishak, N. M. 2011. Teacher-student relationship factor affecting motivation and academic achievement in ESL classroom. Procedia-Social and Behavioral Sciences, 15, 2637-2641.

Yunus, M. M., Salehi, H., \& Amini, M. 2016. EFL Teachers' Cognition of Teaching English Pronunciation Techniques: A Mixed-Method Approach. English Language Teaching, 9(2), 20-42.

Yunus, M., Suraya, A., \& Wan Ali, W. Z. 2009. Motivation in the Learning of Mathematics. European Journal of Social Sciences, 7(4), 93-101. 